\title{
Characterization of the Localized Agri-Food System (SYAL) for the Andean blueberry (Vaccinium meridionale Swartz) in the Boyaca Department, Colombia
}

\section{Caracterización del Sistema Agroalimentario Localizado (SIAL) del agraz (Vaccinium meridionale Swartz) en el departamento de Boyacá, Colombia}
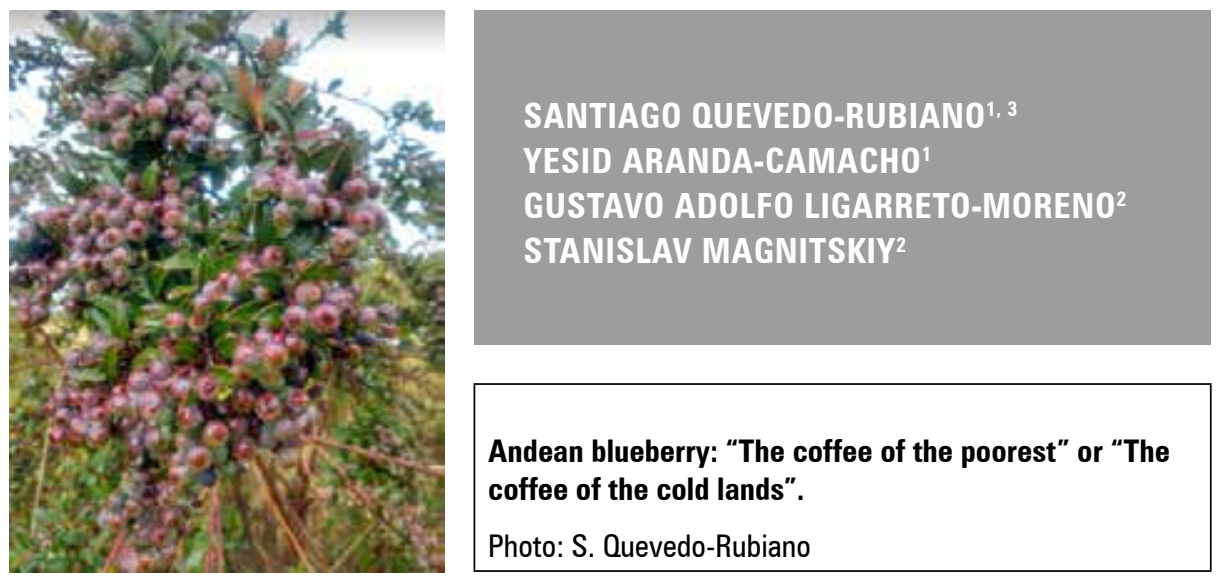

Andean blueberry: "The coffee of the poorest" or "The coffee of the cold lands".

Photo: S. Quevedo-Rubiano

\begin{abstract}
The Andean blueberry (Vaccinium meridionale Swartz), known locally as agraz, possess a high level of anthocyanins and antioxidants and represents a socio-economical, environmental, and cultural alternative in Colombia. However, a characterization of the agri-food system has been done, limiting strategies for its valorization. The objective of this study was to characterize the Localized Agri-food System (SYAL) of the Andean blueberry in the Occidente and Ricaurte provinces of the Boyaca Department of Colombia. Three analytical axes were used within the SYAL approach: territorial anchorage, activation processes, and links between product quality and territory. The farmer product circuit methodology was used to identify agents linked to the product commercialization chain in the territory, and their participation was estimated. Data treatment was performed with descriptive statistics and multivariate analysis, specifically principal component analysis for numerical variables and multiple correspondence analysis for categorical variables. A SYAL was evident in the early stages of consolidation, with exceptional adaptations to the biophysical conditions in the territory. Finally, four groups of actors were identified, where the main discriminating variable was membership in an organization of farmers, a determining condition for business competitiveness in the territory.
\end{abstract}

\footnotetext{
Additional key words: native fruit crops; Ericaceae; agrobiodiversity products; terroir; market.

1 Universidad Nacional de Colombia, Facultad Ciencias Agrarias, Departamento de Desarrollo Rural y Agroalimentario, Grupo de investigación en Gestión y Desarrollo Rural (GIGDR), Bogota (Colombia). ORCID Quevedo-Rubiano, S: 0000-0002-3622-4343; ORCID Aranda-Camacho, Y: 0000-0003-2844-2639

2 Universidad Nacional de Colombia, Facultad Ciencias Agrarias, Departamento de Agronomía, Bogota (Colombia). ORCID Ligarreto-Moreno, G: 0000-0001-9372-6094; ORCID Magnitskiy, S: 0000-0002-3715-1932

3 Corresponding author. squevedor@unal.edu.co
} 


\section{RESUMEN}

El agraz (Vaccinium meridionale Swartz) es una fruta considerada como alimento funcional por su contenido de antocianinas y antioxidantes, posee alto potencial de consumo y representa una alternativa en términos socio-económicos, ambientales y culturales para la población de Colombia. No obstante, no existe una caracterización del sistema agroalimentario, lo cual limita la puesta en marcha de estrategias para su valorización. El objetivo de este trabajo fue caracterizar el Sistema Agroalimentario Localizado (SIAL) de agraz de las provincias de Occidente y Ricaurte del departamento de Boyacá-Colombia. Para el efecto, se utilizaron tres ejes analíticos dentro del enfoque SIAL, a saber: el anclaje territorial, los procesos de activación y el vínculo entre la calidad del producto y el territorio. Para identificar los agentes que se vinculan a la cadena de comercialización del producto se empleó la metodología de Circuitos de productos de origen campesino y se calculó la participación del productor. El tratamiento de los datos se realizó con estadística descriptiva y análisis multivariado, específicamente análisis de componentes principales para variables numéricas, y análisis de correspondencia múltiple para las variables categóricas. Se evidenció un SIAL en estadios tempranos de consolidación con adaptaciones excepcionales a las condiciones biofísicas del territorio. Finalmente, se identificaron cuatro grupos de actores, siendo la principal variable discriminante el hecho de pertenecer a una organización de agraceros, siendo ésta la condición determinante sobre la competitividad empresarial en el territorio.

Palabras clave adicionales: frutales nativos; Ericaceae; productos de la agrobiodiversidad; terroir; mercado.

Received: 18-08-2020 Accepted: 25-11-2020 Published: 02-01-2021

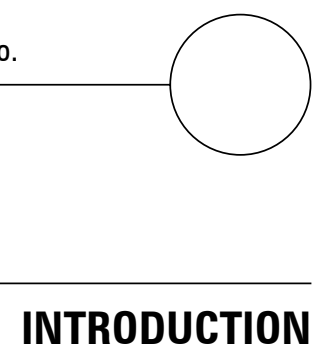

Colombia has comparative and competitive advantages in agriculture because of its geographic location and territorial characteristics, with vast variety and availability of agro-biodiversity resources. The territorial factors linked to elaboration of agricultural products must be viewed in relation to specific territorial conditions to achieve valorization and use of these resources. This could be done with territorial development strategies that identify links between products and territories in order to preserve the origin and in situ production.

This study looked at an endemic product with high potential and little use, i.e. the Andean blueberry (Vaccinium meridionale Swartz), known locally as agraz, mortiño, or vichacha, which, in recent years, has become a promising fruit crop for some territories, with growing demand and recognition because of its nutraceutical and medicinal properties (Gaviria et al., 2009; Torres et al., 2009; Quintero-Quiroz et al., 2019). These properties have generated growing commercial interest to this species with their differential attributes (Çelik et al., 2008; Garzón et al., 2020).

The potential of the Andean blueberry is well-known in some territories of Colombia (Ligarreto, 2009); however, there is a gap in collective action processes, product-territory links, historical and cultural processes, and market dynamics that explain the embeddedness and terroir effect of this product on some provinces in the Boyaca Department. Consequently, an adequate analysis of the localized agri-food system and subsequent strategic actions for activation are limited.

Localized Agri-Food Systems (SYAL) are an alternative approach to achieve value in local products because they catalyze the existing collective action, which is needed for the activation of territorial agri-food resources, on a smallholder scale (Boucher and Reyes, 2016). This approach explains how the biophysical conditions of territories, along with the existent agro-biodiversity, local know-how, and sociocultural relationships around agricultural production in a specific territory, consolidate localized agri-food systems, where local networks of small farmers and small and medium companies are joined in the use of a product in productive activities. These actors cooperate in the development of innovation processes to take advantage of the differential quality of local products, favoring the preservation of lifestyles rooted in territorial culture (Bérard and Marchenay, 1996; Boucher and Reyes, 2016; Boucher and RiverosCañas, 2017; Camacho et al., 2017). 
As a conceptual and methodological tool for territorial intervention, the SYAL approach elucidates and promotes endogenous development through the production, transformation, and commercialization of products and services with differential or specific attributes, strengthening networks of organized producers and fostering the development of collective actions that lead to the valorization of deep-rooted resources (Boucher and Riveros-Cañas, 2017; Tolentino et al., 2018; Red SYAL México, 2019).

The potential importance of this agrobiodiversity product for agricultural communities in Boyaca led to this study's characterization of the Localized AgriFood System (SYAL) for V. meridionale in the Occidente and Ricaurte provinces of the Boyaca Department, using the analytical axes of the SYAL approach.

\section{MATERIALS AND METHODS}

The study was carried out in 2019 in the municipalities that reported the largest planted area and the highest production rates nationwide of $V$. meridionale: Chiquinquira and San Miguel de Sema in the Occidente province, and Raquira and Tinjaca in the Ricaurte province in the Boyaca Department (Ligarreto et al., 2011; Agronet, 2020).

The characterization was developed using the three dimensions for the analysis of the SYAL approach (Boucher and Poméon, 2010; Camacho et al., 2017): 1) territorial anchorage: the territory, the $V$. meridionale growth and cultivation system, the actors linked to the SYAL, and the local know-hows and innovations; 2) activation processes: involvement of actors and collective actions for the SYAL in the territory; 3 ) links between the product quality and the territory: valorization and reputation of the product.

Qualified informants in the area were consulted, to whom the primary information collection tools were applied, addressing the different agents that make up the links in the product value chain (Tab. 1). The variables for each type of actor were selected from documentary research of the SYAL approach (Muchnik and Sautier, 1998; Muchnik, 2006; Rodríguez-Borray and Rangel-Moreno, 2005; Santacruz et al., 2019), the schools of the proximity economies (Torre and Rallet, 2005), and the economics of cultural approach (Ray, 1998).
Given the lack of exact records that clearly identify producers linked to the $V$. meridionale system in the territory, the qualified informants were selected with non-probabilistic, intentional and convenience sampling, following the snowball technique described by Espinoza (2017), starting with officials from the support institutions in the territory. The fieldwork was carried out between September and December of 2019.

On the other hand, the rural product circuit methodology (Gutierréz, 2016; Rubiano, 2017) was used to identify agents linked to the agri-food supply chain. The marketing margins were identified based on the difference between the consumer price and the different prices during the commercialization process, with which the participation per link (PPL) and the producer's participation (PP) were calculated (Mendoza, 1995; Caldentey and de Haro, 2004).

For the data treatment, a principal component analysis (PCA) was performed for the numerical variables to observe the behavior and interactions, and a multiple correspondence analysis (MCA) was employed for the categorical variables to observe the data behavior and reduce dimensionality (Tab. 2). Subsequently, a cluster analysis was performed, where four groups of producer-gatherers were established from the discriminating categorical variables using the Ward method, which differentiates covariances (De la Hoz et al., 2018). The data were processed using the statistical program R-Project 2.12.2. Finally, the production areas of $V$. meridionale were delimited and zoned using QGIS 3.0 with the identification and classification and with the geographical coordinates of the locations of the territorial actors.

\section{RESULTS AND DISCUSSION}

\section{Territorial anchorage}

\section{Territory}

Figure 1 shows the location of the $V$. meridionale producers/collectors in the territory, mainly in the mountain areas. Similarly, according to the zoning carried out by Muñoz et al. (2009), Boyaca sees high altitudinal use, with a total of 42,360 ha $(76 \%$ of the total); in addition, moderately suitable areas have 12,603 ha (22\%). Unsuitable areas have 986 ha (2\%). 
Table 1. Surveyed actors involved in the V. meridionale system in Boyaca (Colombia).

\begin{tabular}{|c|c|c|c|}
\hline Link & Actor or number of actors consulted & Municipality & Total actors \\
\hline \multirow{4}{*}{ Producer-fruit collector } & 16 & Raquira & \multirow{4}{*}{36} \\
\hline & 4 & San Miguel de Sema & \\
\hline & 10 & Tinjaca & \\
\hline & 24 & Chiquinquira & \\
\hline \multirow{3}{*}{ Associations } & ASOTORRES & Raquira & \multirow{3}{*}{3} \\
\hline & ASOFRUSANS & San Miguel de Sema & \\
\hline & ASOAGOPECTIN & Tinjaca & \\
\hline \multirow{7}{*}{ Supporting institutions } & Department Agriculture Secretary & Boyaca & \multirow{5}{*}{8} \\
\hline & Municipality Planning Secretary & Raquira & \\
\hline & Municipality Planning Secretary & Tinjaca & \\
\hline & Agricultural Development and Environment Secretary & San Miguel de Sema & \\
\hline & National association of peasant users (ANUC) of Ráquira & Raquira & \\
\hline & AGRODIVA & Chiquinquira & \multirow{2}{*}{0} \\
\hline & Fundación San Isidro & Raquira & \\
\hline \multirow{2}{*}{ Agroindustry } & El Robledal & Tinjaca & \multirow{2}{*}{2} \\
\hline & FROOMID S.A.S & Raquira & \\
\hline \multirow{7}{*}{ Commercializer } & 2 & Raquira & \multirow{7}{*}{9} \\
\hline & 1 & Tinjaca & \\
\hline & 1 & San Miguel de Sema & \\
\hline & 1 & Chiquinquira & \\
\hline & 2 & Corabastos & \\
\hline & 1 & Paloquemao & \\
\hline & 1 & Codabas & \\
\hline \multicolumn{3}{|l|}{ Total actors surveyed } & 58 \\
\hline
\end{tabular}

Table 2. Numerical variables and evaluated categories of the V. meridionale system in Boyaca (Colombia).

\begin{tabular}{|c|l|l|}
\hline \multicolumn{1}{|c|}{ Type } & \multicolumn{1}{|c|}{ Variable } & \\
\hline \multirow{4}{*}{ Numerical } & Area of the farm & ha \\
\cline { 2 - 4 } & Area dedicated to $V$. meridionation \\
\cline { 2 - 3 } & Production estimated in the first cycle & ha \\
\cline { 2 - 3 } & Production estimated in the second cycle & $\mathrm{kg}$ \\
\cline { 2 - 3 } & Production estimated per year & $\mathrm{kg}$ \\
\cline { 2 - 3 } & Number of plants-sowing density & Number of plants \\
\cline { 2 - 3 } & Workers in V. meridionale & Number of persons \\
\cline { 2 - 3 } & Frequency of recollection & days per week \\
\cline { 2 - 3 } & Period with V. meridionale crop & years \\
\hline
\end{tabular}




\section{Table 2 continuation}

\begin{tabular}{|c|c|c|}
\hline Type & Variable & Codification \\
\hline \multirow{19}{*}{ Categorical } & Type of the labor force & Family $=F$, Hired $=$ C, Family and hired $=F C$ \\
\hline & Education level & $\begin{array}{l}\text { Primary incomplete }=E 1 \text {, Primary complete }=E 2, \\
\text { High school incomplete }=E 3 \text {, High school complete }=E 4 \text {, Professional }=E 5\end{array}$ \\
\hline & Differentiation of labor force according to sex & $Y_{e s}=1, N_{0}=0$ \\
\hline & Recognition of quality & Yes $=1, \mathrm{~N}_{0}=0$ \\
\hline & Property of the farm & No $=0$, Yes $=1$ \\
\hline & Type of use & In the wild $=S$, Cultivated $=C$ \\
\hline & Production type & Family $=\mathrm{F}$, Farmer $=\mathrm{C}$, Entrepreneur $=\mathrm{E}$ \\
\hline & Access to public services & Electricity $=\mathrm{L}$, Electricity and water $=\mathrm{LA}$, Water $=\mathrm{A}, \mathrm{N}=$ No access \\
\hline & Irrigation system & Yes $=1$, No $=0$ \\
\hline & Principal activity is $V$. meridionale & Yes $=1, \mathrm{~N}_{0}=0$ \\
\hline & $\begin{array}{l}\text { Realization of other activities apart from } V \text {. } \\
\text { meridionale }\end{array}$ & Yes $=1, \mathrm{~N}_{0}=0$ \\
\hline & Auto consumption & Consumer $=\mathrm{C}$, Sales $=\mathrm{V}, \mathrm{C}$ and $\mathrm{V}=\mathrm{CV}$ \\
\hline & Recognition of the benefits for the health & Yes $=1, \mathrm{~N}_{0}=0$ \\
\hline & Access to credit & Yes $=1, \mathrm{No}_{0}=0$ \\
\hline & Agricultural technical assistance & Yes $=1, \mathrm{~N}_{0}=0$ \\
\hline & Membership in association & Yes $=1, \mathrm{~N}_{0}=0$ \\
\hline & Membership in association of $V$. meridionale & Yes $=1, \mathrm{~N}_{0}=0$ \\
\hline & $\begin{array}{l}\text { Existence of the resource to break the seasonali- } \\
\text { ty of the production }\end{array}$ & $Y_{e s}=1, N_{0}=0$ \\
\hline & Recognition of "varieties" of $V$. meridionale & $Y_{e s}=1, N_{0}=0$ \\
\hline
\end{tabular}

These data demonstrate the exceptional adaptation of this species to the territorial biophysical conditions, making it endemic to the Andes in the so-called "Belt of the Ericaceae" (Luteyn, 1989). However, its use is limited to areas with altitudes above 2,600 m a.s.l., where high altitude areas are mainly used for livestock production (MADR, 2019).

Previously, $V$. meridionale plants were eradicated by territorial agents, who were unaware of their potential. However, the increase in demand resulted in the fruit price reaching its maximum historical value, 40,000 Colombian peso $/ \mathrm{kg}$, between 2010 and 2012, encouraging a large number of agents to take advantage of this product. Subsequently, the growing domestic supply from different territories resulting from the market opportunity saw prices stabilizing at a maximum of 20,000 Colombian peso $/ \mathrm{kg}$ and minimum of 2,000 Colombian peso/kg paid on farms.

On the other hand, all survey participants acknowledge that, in their childhood, they consumed the fruits of this species when recollecting firewood or going to school, evidencing use for 25 years by the majority of actors, that is, since 1994. However, the use of this fruit crop by the majority of domestic consumers started in 2008 and was reflected by its growing demand and increases in market prices.

It is noteworthy that $3 \%$ of the actors over 50 years of age recognized a benefit in this plant, whose parents made homemade juices with a hand stone, indicating use by some actors for more than 60 years, that is, since 1960 approximately. However, this fruit has not been part of the culinary tradition in typical dishes or ancestral recipes, which constitute the basic diet of the people in the Altiplano Cundiboyacense (Vega-Castro and López-Barón, 2012).

Likewise, at the institutional level, Raquira is the only municipality that recognizes $V$. meridionale as the main commercialized agricultural product, where the only association of growers is in Torres village, the Association of Producers of the Vereda de Torres (ASOTORRES) (Amaya-Rodríguez, 2018; MADR, 2019). 


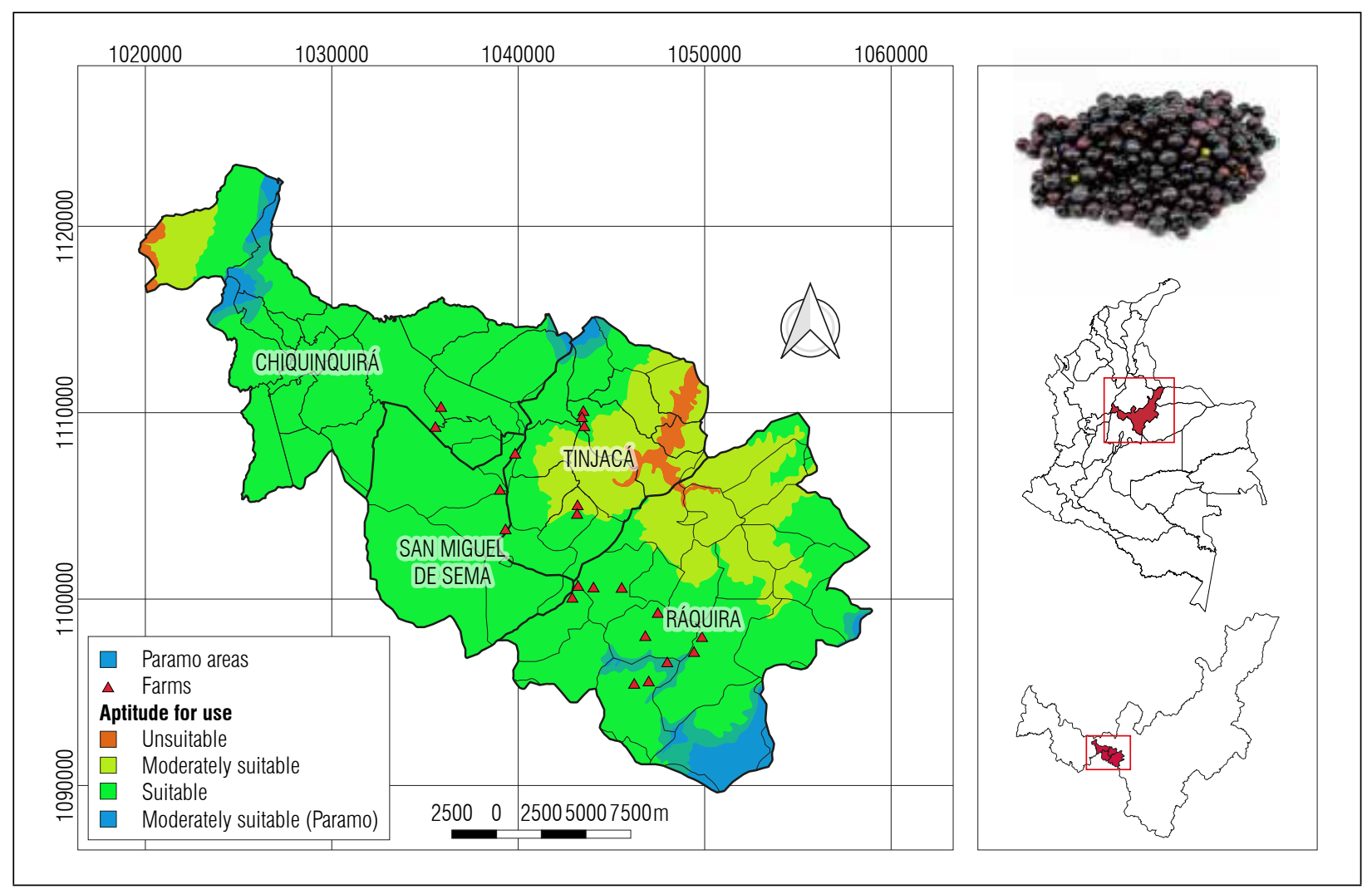

Figure 1. Zonification of $V$. meridionale use in the territory.

\section{The productive system of agraz in the territory}

The use of this species involves both established crops and plants grown in the wild, with adaptation to the Colombian high Andean areas, located in montane areas between 2,000 and 3,200 $\mathrm{m}$ a.s.l., where this species grows in the wild (Torres et al., 2009).

At the domestic level, it is found in the high areas of the departments Boyaca, Antioquia, Cundinamarca, Cauca, Huila, Nariño, and Santander (Ligarreto, 2009, 2011), and at the departmental level, mainly in the municipalities of Raquira, Tinjaca, San Miguel de Sema and Chiquinquira (Ligarreto et al., 2011), although it is also found in Samaca, Combita, Susacon, Arcabuco, and Paipa.

The system is made up of small producer-gatherers with an average area of 2 ha, within which $V$. meridionale is dispersed in cultivation or in the wild. Eightythree percent of the actors carry out wild collection, and $17 \%$ have cultivation established with plant rescue. The latter transplants plants from wild populations to a farm.
The main limitation for the commercialization and market positioning of this fruit is the absence of established crops (Ligarreto, 2009). For this reason, inconsistencies are observed in the yields reported by state institutions because they are reported in tons per hectare; however, given the wild nature of this system, they should be reported as values per plant.

Considering the timing of harvests and the production values reported per department in 2018 (Agronet, 2020), a clear seasonality of berry production was evidenced, related to average precipitation periods (IDEAM, 2020) because of the wild nature of the species and the absence of irrigation systems (Fig. 2). As a result, the local population is seeking alternatives to generate extra resources. Therefore, all actors carry out activities parallel to $V$. meridionale, including agricultural activities such as the cultivation of potatoes, beans, corn, tomatoes, tree tomatoes, cape gooseberries, and blackberries, etc., and non-agricultural activities such as clay handicrafts, artisanal knitting, mining, per-hour field labor, and trading, among others. There are very diverse activities connected to the $V$. meridionale system. 

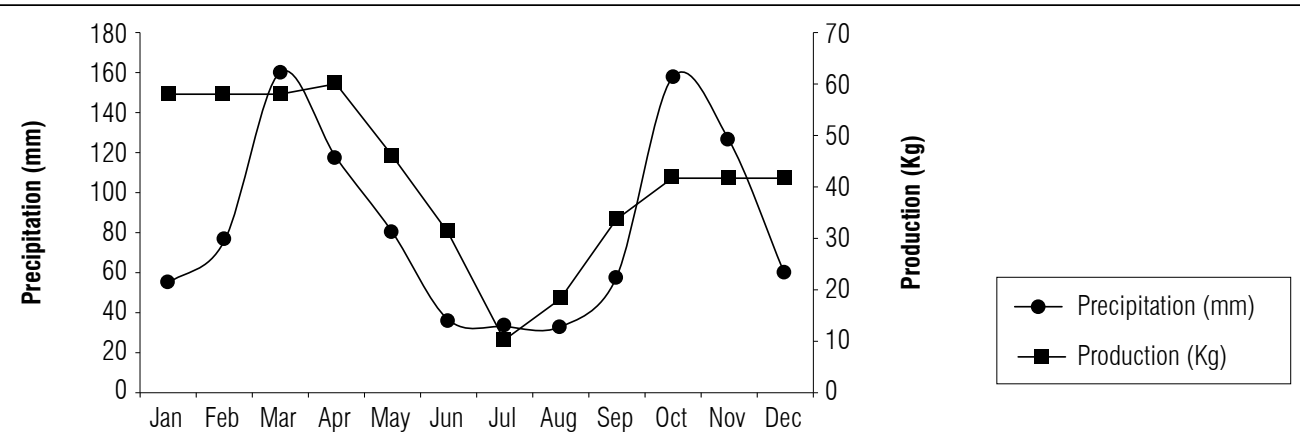

Figure 2. Relationship between the precipitation rates (1981-2010) and the production of V. meridionale in the Boyaca Department (Colombia).

\section{Actors from the territory linked to the agraz SYAL in Boyaca}

Actors in the localized agri-food system for agraz include: producers-collectors, associations, institutions, foundations, berry processors, and marketers (Tab. 1 ); there is no direct relationship between suppliers of productive factors and producer-collectors.

The average age of the actors was 52 years, with a mode of 62 years and a range of 30 to 70 . There was a notable distribution in age data but with a tendency for increased ages. These data coincide with that reported by López et al. (2018), who established a relationship between economic growth and the migratory processes of younger populations to cities, accentuated by the unequal distribution of income in the commercial process.

On the other hand, $64 \%$ of the producer-gatherers did not recognize qualities or carry out product selection processes, while the remaining $36 \%$ did, which is reflected in the final quality of the product (Torres et al., 2009).

Only $17 \%$ of the actors belonged to the ASOTORRES, which has provided institutional visibility and access to goods and services offered by the territorial institution. Its members have received assistance services; therefore, they select the product and know the number of plants in each property. Likewise, the collective actions of ASOTORRES have resulted in commercial success, providing market power and increasing income in the commercial process (Caldentey and Gómez, 1993).

$V$. meridionale is a species that has been partially ignored by science and rural development programs (Ligarreto, 2009); no varieties have been identified to date. However, empirically, $11 \%$ of the producergatherers in the studied area recognized the existence of two ecotypes, known to the local population as the "variety" "Estrella" and "Círculo", while the remaining $89 \%$ only perceive the common Andean blueberry.

The Principal Component Analysis (PCA) revealed that there was a direct relationship between production and number of plants on a property; likewise, a direct relationship was observed between the age of the producers-collectors and the time of use (Tab. 3). In other words, the greater the number of plants on a property, the greater the reported production was; however, yield was not related to farm area but to

Table 3. Principal Component Analysis of the numerical variables in the agraz SYAL in Boyaca (Colombia).

\begin{tabular}{|l|c|c|c|c|c|c|}
\hline Variables & Dim $1^{*}$ & Contribution & Variance & Dim 2* & Contribution & Variance \\
\hline Production per year & -0.03 & 0.07 & 0 & 0.69 & 38.68 & 0.49 \\
\hline Number of plants & 0.04 & 0.12 & 0 & 0.6 & 28.64 & 0.36 \\
\hline Number of workers & 0.67 & 29.64 & 0.45 & 0.49 & 18.99 & 0.24 \\
\hline Age & 0.59 & 22.94 & 0.35 & -0.4 & 12.67 & 0.16 \\
\hline Period of use & 0.84 & 47.22 & 0.72 & -0.11 & 1.01 & 0.01 \\
\hline
\end{tabular}

${ }^{*}$ Dim (Dimension): Cartesian coordinates. 
the number of plants on the farm. Similarly, for the correlation between the variables of age and time of use, two generations were observed: the pioneering generation, which reported a higher number of years of use, and the younger generation, with fewer years of use.

A multiple correspondence analysis (MCA) was carried out, where different relationships were observed between the evaluated variables (Tab. 4). The following variables were included: 1) membership in agraz producer associations; 2) assessorship for phytosanitary terms; 3) recognition of quality; 4) type of use; 5 ) educational level; 6) recognition of $V$. meridionale "varieties"; 7) farm ownership.

These variables corresponded to categorical-qualitative variables that were used for the cluster classification (Fig. 3).

Cluster 1: Corresponds to $17 \%$ of the producer-collectors. This group was characterized by membership in
ASOTORRES, with access to different benefits such as technical and phytosanitary assistance. The labor force was usually familial or hired, who carried out product selection and classification processes. This group also possessed crops established with plant rescue from the wild.

Cluster 2: Corresponds to $60 \%$ of the producer-collectors. This group was not linked to any agraz association. The labor force was mainly familial, and the harvest was usually done with plants in the wild. Finally, a large portion did not keep a record of the number of plants or their productivity.

Cluster 3: Corresponds to $9 \%$ of the producer-gatherers. This group recognized the $V$. meridionale ecotypes; in addition, it contained professionals and people with a high school diploma.

Cluster 4: Corresponds to $14 \%$ of the producer-collectors. This group included those individuals who did not belong to associations or own land.

Table 4. Multiple correspondence analysis of the categorical variables in the agraz SYAL in Boyaca (Colombia).

\begin{tabular}{|c|c|c|c|c|c|c|c|}
\hline Class & Variable & T-value & p-value & Class.Cat ${ }^{*}$ & Cat.Class $^{* *}$ & Global & Weight \\
\hline \multirow{7}{*}{1} & Assessorship in phytosanitary practices-Yes & 5.02 & 0.000 & 100.00 & 100.00 & 16.70 & 6 \\
\hline & Membership in association of agraz-Yes & 5.02 & 0.000 & 100.00 & 100.00 & 16.70 & 6 \\
\hline & Resources for seasonality of harvest-Yes & 5.02 & 0.000 & 100.00 & 100.00 & 16.70 & 6 \\
\hline & Membership in association-Yes & 3.68 & 0.000 & 54.50 & 100.00 & 30.60 & 11 \\
\hline & Recognition of quality-Yes & 3.50 & 0.000 & 50.00 & 100.00 & 33.30 & 12 \\
\hline & Type of use-C & 2.93 & 0.003 & 66.70 & 66.70 & 16.70 & 6 \\
\hline & Labor force-FC & 2.56 & 0.010 & 75.00 & 50.00 & 11.10 & 4 \\
\hline \multirow{7}{*}{2} & Assessorship in phytosanitary practices-No & 3.50 & 0.000 & 80.00 & 100.00 & 83.30 & 30 \\
\hline & Membership in association of agraz-No & 3.50 & 0.000 & 80.00 & 100.00 & 83.30 & 30 \\
\hline & Resource for seasonality of harvest-No & 3.50 & 0.000 & 80.00 & 100.00 & 83.30 & 30 \\
\hline & Recognition of quality-No & 2.84 & 0.005 & 83.30 & 83.30 & 66.70 & 24 \\
\hline & Labor force-F & 2.57 & 0.010 & 76.70 & 95.80 & 83.30 & 30 \\
\hline & Type of use-S & 2.57 & 0.010 & 76.70 & 95.80 & 83.30 & 30 \\
\hline & Membership in association-No & 2.41 & 0.016 & 80.00 & 83.30 & 69.40 & 25 \\
\hline \multirow{2}{*}{3} & Educational level-E5 & 3.81 & 0.000 & 100.00 & 100.00 & 8.30 & 3 \\
\hline & Recognition of "varieties" of $V$. meridionale-Yes & 2.21 & 0.027 & 50.00 & 66.70 & 11.10 & 4 \\
\hline \multirow{2}{*}{4} & Educational level-E3 & 3.81 & 0.000 & 100.00 & 100.00 & 8.30 & 3 \\
\hline & Proprietary of the farm-No & 2.01 & 0.045 & 40.00 & 66.70 & 13.90 & 5 \\
\hline
\end{tabular}

${ }^{*}$ Class.Cat (Class.Category): Percentage of people in the class who are in that category.

${ }^{* *}$ Cat.Class (Category.Class): Percentage of people who are in that category. 


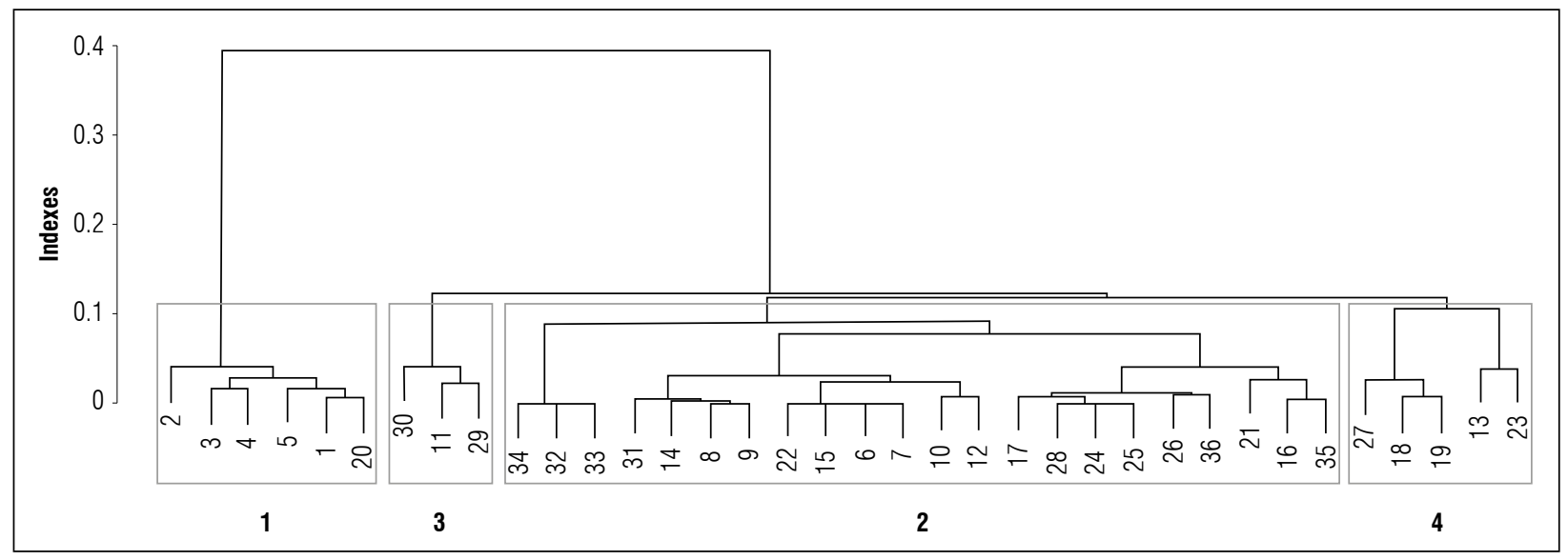

Figure 3. Dendrogram of the principal producers-gatherers of $V$. meridionale in the territory.

The variable with the greatest weight for differentiating clusters was membership in an association of agraz producers (ASOTORRES) because it provides visibility for producers at the institutional level and the channeling of resources, which determine success in this specific system.

On the other hand, six institutions were identified in the territory: The Secretary of Agriculture of the Governor of Boyaca, the Secretary of Planning of Raquira, the Secretary of Planning of Tinjaca, the Secretary of Agricultural Development and Environment of San Miguel de Sema, the ANUC of Raquira, the AGRODIVA Foundation, and the San Isidro Foundation. In addition, the Productive Alliances Project inter-institutionally links various agents that promote the development of the association.

The marketing of fresh berries and processed products was identified. For the former, inter-city and inter-municipal intermediaries were identified who sell the product in $25 \mathrm{~kg}$ baskets, traveling in small vehicles (cars or motorcycles) or shipping the baskets. Of these, $40 \%$ of the marketers carried out the product selection process, observing a low level of selection; however, fewer producer-collectors carried out this process. Likewise, all marketers recognized the different ecotypes or "varieties", which discriminated by location, namely: the Boyaca, Cauca, Nariño and Medellin "varieties". The classification of the "varieties" by the marketers was different from that carried out by the producers-gatherers who identified "varieties" of $V$. meridionale (cluster 3 ).

\section{Local know-hows and innovations}

The commercialization of this product at the beginning of the 90s was carried out in wood boxes or straw baskets, transported on the back of donkeys or mules, and the prices by weight, in arrobas or bushels, were subjectively negotiated in the Chiquinquira market without scales. These prices were relatively low, which is why this product was known as "the coffee of the poorest" or "the coffee of the cold lands". Currently, each intermediary has a digital scale to negotiate prices.

There are currently two processing companies in the territory: El Robledal of Tinjaca, which has been making jams and preserves since the 1990s; and FroMID of Raquira, an initiative that started with a rural, young woman who has been making jams, meat seasonings, wine, and juices since 2016. Both companies use traditional rural agribusiness processes and environmental, sustainable development (Red SYAL México, 2019).

On the other hand, in Raquira, some territorial agents use agri-ecological tourism in the high mountain areas of the municipality, calling it "La ruta del agraz", for a multifunctional production alternative (Torres, 2013).

Likewise, the $V$. meridionale system is a sustainable alternative in economic, social, and environmental terms (Ligarreto, 2009), promoting the care of forests, waterways and sub-paramo areas, such as the 
Rabanal paramo and the Robledal Forest Reserve, unique areas in the territory. Since the territorial actors do not use external products and share a portion of the production with wild birds, they consider themselves as "the friends of birds".

\section{Activation processes}

\section{Articulation of SYAL actors and collective actions in the territory}

Among the actors identified in the territory, there are competition-cooperatives. Members of ASOTORRES cooperate through structural collective actions (Camacho et al., 2017). Their success lies in the identification of a common objective (Neumeier, 2017), "the market", identifying it as the main obstacle in the commercial process. The marketing margins showed that the average producer participation (PP) was approximately $41-45 \%$, yet ASOTORRES members have stable prices in the supply chain because they sell fruits directly to restaurants outside the territory (Fig. 4; Quevedo-Rubiano, 2020).

Therefore, this system can use Short Marketing Circuits in the search for new alternatives that contribute to the inclusion of rural territories (Boucher and Riveros-Cañas, 2017). On the other hand, ASOTORRES is currently carrying out an inter-institutional project for the construction of post-harvest facilities that add utility over time (Caldentey and Gómez, 1993) to the seasonality of production.

Therefore, the territory presents passive advantages because of the presence of specific elements but not a marked presence of active advantages, such as the "activation" of passive advantages through the performance of collective actions, both structural and functional (Red SYAL México, 2019).

\section{Links between product quality and territory}

All producers-collectors recognized the properties of this product; likewise, $89 \%$ consumed it regularly. They knew that this fruit offers protection from cancer, keeps cholesterol low, heals the flu and, in general, raises the body's defenses. Therefore, it is commonly consumed on an empty stomach, mainly in juices or fresh, similar to cape gooseberries (Fischer and Melgarejo, 2020) or mortiño (Vaccinium floribundum) in Ecuador, which has a large number of medicinal uses by the local population (Coba-Santamaría et al., 2012; Guijarro-Fuertes et al., 2019). Currently, in the municipalities of Tinjaca and Raquira, agraz cultivation is an indicator of property value, increasing rental or sale prices.

Similarly, in the product marketing chain, regional merchants in wholesale markets, such as Corabastos and Codabas Bogota, prefer to commercialize agraz

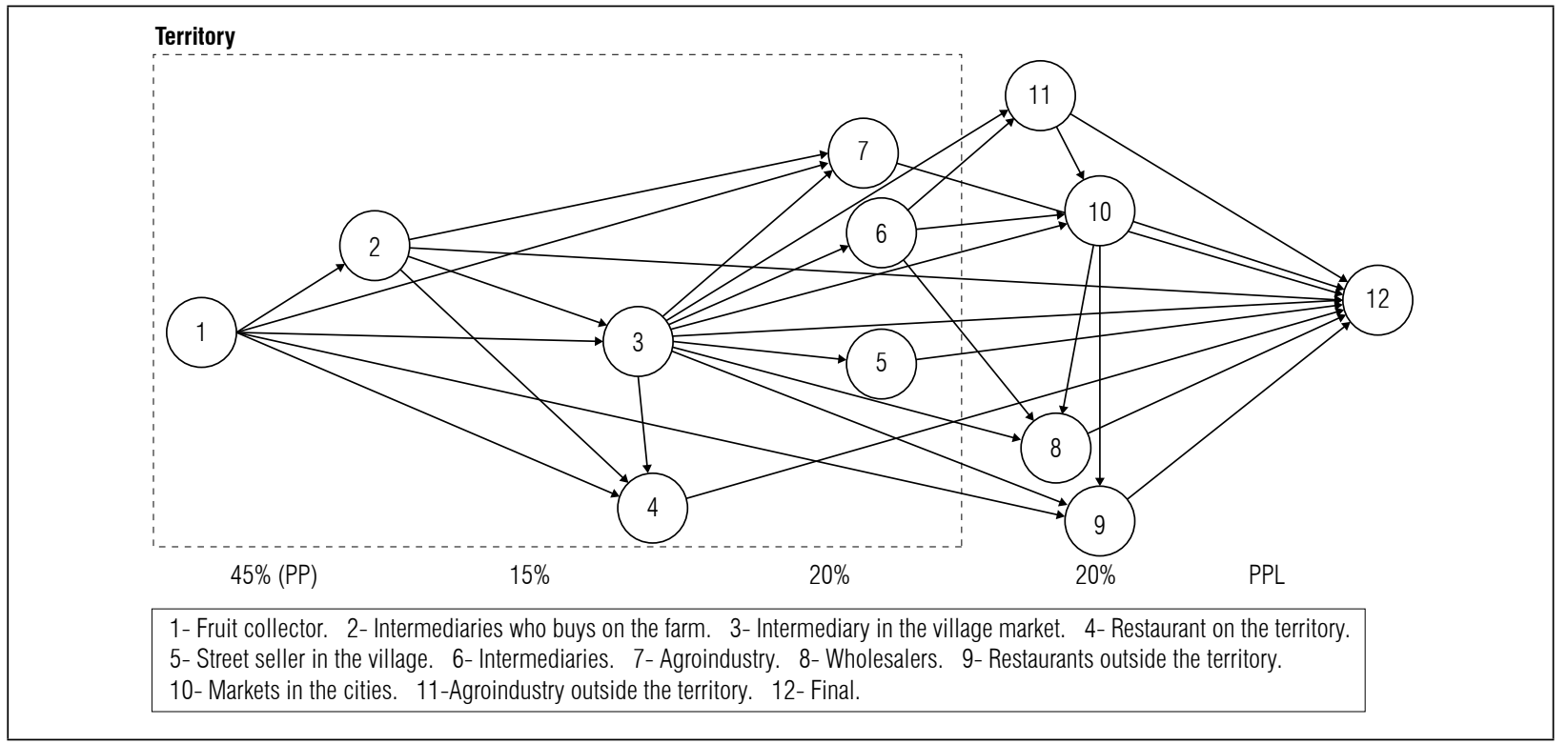

Figure 4. Agent Links in the agraz marketing chain. 
from Boyaca because it is perceived as providing greater health benefits and because it has better postharvest resistance than products from other areas of the country.

$V$ meridionale plants from other areas of the country provide fruits from Nariño that are reported as sweeter and more opaque than fruits from Boyaca (probably another species), while agraz fruits from Medellin have a better appearance but are mild in flavor with a higher water content. The berries from Cauca are large with a high acidity. The characteristics of this resource vary depending on the biophysical conditions of the territory; however, there are no studies on this aspect (Magnitskiy and Ligarreto, 2009).

Finally, the relationship between the agrobiodiversity-territory product and the agraz SYAL in Boyaca requires development of functional collective actions that allow stakeholders to identify productive practices and document historical processes that affect the differential quality and specificity of the product in advance (Aranda-Camacho et al., 2014; Belletti et al., 2017). These actions would develop a strategy for differentiation of the product-territory that contributes to the development of rural territory where the SYAL is found in the medium-term.

\section{CONCLUSIONS}

The agraz production system in the Boyaca Department is made up of a network of producers-collectors, small farmer organizations, small transformation enterprises, marketing agents and support institutions who have been cooperating and coordinating to establish a SYAL for this product in the territory. The product-territory links affect the differential quality of agraz in this territory, as compared to other substitute products for the Vaccinium genus that compete with leadership logic in costs (commodity) and that are currently produced and marketed in the country. This plant has exceptional adaptation to the biophysical conditions of this territory, reflecting co-evolution with the "Belt of Ericaceae". However, to date, the territory has passive advantages but does not have a marked presence of active advantages, with the exception of ASOTORRES, the only association of agrazeros (the actors involved in the $V$. meridionale system) in the territory, which carries out "activation" processes through structural collective actions.
The categorical variables turned out to be discriminating in this specific system, identifying four groups of actors where membership in an organization of agrazeros was decisive for business competitiveness in the territory. This evidenced the need to strengthen existing and emerging collective actions, both structurally and functionally, to achieve significant improvements in the competitiveness of the system.

This territory has processes of product appreciation, advanced by the rural agroindustry, agro-tourism (" $\mathrm{La}$ ruta del agraz"), and institutional presence linked to ASOTORRES, such as AGRODIVA, the ANUC of Raquira, the San Isidro Foundation, and the Productive Alliances Project.

Advance ecotype typification processes for this crop are recommended to strengthen product quality, bearing in mind that an unidentified heterogeneity disables the standardization and homogeneity of local quality. Given the wild nature of $V$. meridionale, yield data should be managed in terms of plants $(\mathrm{kg} /$ plant) and not per unit area $\left(\mathrm{kg} \mathrm{ha}^{-1}\right)$.

Conflict of interests: The manuscript was prepared and reviewed with the participation of the authors, who declare that there exists no conflict of interest that puts at risk the validity of the presented results.

\section{BIBLIOGRAPHIC REFERENCES}

Agronet. 2020. Estadística. Producción nacional por cultivo. In: https://www.agronet.gov.co/estadistica/Paginas/ home.aspx?.cod=1; consulted: August, 2020.

Amaya-Rodríguez, C.A. 2018. Ordenamiento territorial departamental de Boyaca. pp. 1-102. In: http://www. dapboyaca.gov.co/wp-content/uploads/2018/09/ESTRUCTURA-BIOFÍSICA.pdf; consulted: September, 2019.

Aranda-Camacho, Y., A. Gómez, and E. Ramos. 2014. Tipificación de los vínculos producto típico-territorio: una metodología con aplicación empírica en productos agroalimentarios de la región andina de Colombia. Agroalimentaria 20(38), 15-33.

Belletti, G., A. Marescotti, and J.-M. Touzard. 2017. Geographical indications, public goods, and sustainable development: The roles of actors' strategies and public policies. World Develop. 98, 45-57. Doi: 10.1016/j. worlddev.2015.05.004

Bérard, L. and P. Marchenay. 1996. La construcción social de los productos de la tierra. Agricult. Sociedad 80, 31-56. 
Boucher, F. and T. Poméon. 2010. Reflexiones en torno al enfoque SYAL : Evolución y avances desde la Agroindustria Rural (AIR) hasta los sistemas Agroalimentarios Localizados (SYAL). pp. 1-13. In: The $116^{\text {th }}$ EAAE Seminar "Spatial Dynamics in Agri-food Systems: Implications for for Sustainability and Consumer Welfare". CIRAD-IICA/UMR Innovation. UA Chapingo-CIRAD; CIESTAAM-UMR, Parma, Italy.

Boucher, F. and J.A. Reyes. 2016. Guía metodológica SYAL: I. Activación de Sistemas Agroalimentarios Localizados (SYAL) II. Activación Territorial con Enfoque de Sistemas Agroalimentarios Localizados (AT-SYAL). $2^{\text {nd }}$ version. IICA; Cirad; REDSYAL, Mexico, DC.

Boucher, F. and A. Riveros-Cañas. 2017. Dinamización económica incluyente de los territorios rurales: alternativas desde los Sistemas Agroalimentarios Localizados y los Circuitos Cortos de Comercialización. Estudios Latinoamer. 40(40), 39-58. Doi: 10.22201/ cela.24484946e.2017.40.61580

Caldentey, P. and T. de Haro. 2004. Comercialización de productos agrarios. $5^{\text {th }}$ ed. Ed. Mundi-Prensa, Madrid.

Caldentey, P. and A. Gómez. 1993. Economía de los mercados agrarios. Ediciones Ediciones Mundi-Prensa, Madrid.

Camacho, J.H., F.C. Escoto, M.I.P. Rangel, and A.C. Vargas. 2017. Clúster y SYAL, enfoques divergentes en estudios del desarrollo territorial. Interciencia 42(1), 51-57.

Çelik, H., M. Özgen, S. Serçe, and C. Kaya. 2008. Phytochemical accumulation and antioxidant capacity at four maturity stages of cranberry fruit. Sci. Hortic. 117(4), 345-348. Doi: 10.1016/j.scienta.2008.05.005

Coba-Santamaría, P., D. Coronel, K. Verdugo, M.F. Paredes, E. Yugsi, and L. Huachi. 2012. Estudio etnobotánico del mortiño (Vaccinium floribundum) como alimento ancestral y potencial alimento funcional. La Granja 16(2), 5-13. Doi: 10.17163/lgr.n16.2012.01

De la Hoz, E., T. Fontalvo, and A. Mendoza. 2018. Métodos multivariantes aplicados a la efectividad. INGE CUC 14(1), 133-140. Doi: 10.17981/ingecuc.14.1.2018.12

Espinoza, S.I. 2017. Tipos de muestreo aleatorio. In: Universidad Nacional Autónoma de Honduras, Facultad de Ciencias Médicas, Unidad de Investigación Científica, http://www.bvs.hn/Honduras/Embarazo/Criterios.de.Muestreo.Marzo.2016.pdf; consulted: June, 2019.

Fischer, G. and L.M. Melgarejo. 2020. The ecophysiology of cape gooseberry (Physalis peruviana L.) - an Andean fruit crop. A review. Rev. Colomb. Cienc. Hortic. 14(1), 76-89. Doi: 10.17584/rcch.2020v14i1.10893

Garzón, G.A., C.Y. Soto, M. López-R., K.M. Riedl, C.R. Browmiller, and L. Howard. 2020. Phenolic profile, in vitro antimicrobial activity and antioxidant capacity of Vaccinium meridionale swartz pomace. Heliyon 6(5), e03845. Doi: 10.1016/j.heliyon.2020.e03845
Gaviria, C.A., C.I. Ochoa, Y.N. Sánchez, C.I. Medina, M. Lobo, P.L. Galeano, A.J. Mosquera, A. Tamayo, Y. Lopera, and B.A. Rojano. 2009. Propiedades antioxidantes de los frutos de agraz o mortiño (Vaccinium meridionale Swartz). pp. 93-112. In: Ligarreto, G. (ed.). Perspectivas del cultivo de agraz o mortiño (Vaccinium meridionale Swartz) en la zona altoandina de Colombia. Universidad Nacional de Colombia, Bogotá.

Guijarro-Fuertes, M., M.J. Andrade-Cuvi, J. Bravo-Vasquez, L. Ramos-Guerrero, and M.G. Vernaza. 2019. Andean blueberry (Vaccinium floribundum) bread: physicochemical properties and bioaccessibility of antioxidants. Food Sci. Technol. 39, 56-62. Doi: 10.1590/fst.30317

Gutierréz, O. 2016. Políticas para mejorar la participación de pequeños productores en la comercialización de alimentos en Colombia. MSc thesis. Facultad de Ciencias Agraria, Universidad Nacional de Colombia, Bogota.

IDEAM, Instituto de Hidrología, Meteorología y Estudios Ambientales de Colombia. 2020. Tiempo y clima. Promedios climatologicos 1981-2010. In: http://www. ideam.gov.co/web/tiempo-y-clima/clima; consulted: August, 2020.

Ligarreto, G. 2009. Perspectivas del cultivo de agraz o mortiño (Vaccinium meridionale Swartz) en la zona altoandina de Colombia. Universidad Nacional de Colombia, Bogota.

Ligarreto, G. 2011. Agraz (Vaccinium meridionale Swartz). Algunas prácticas de cultivo y poscosecha. Universidad Nacional de Colombia, Bogota.

Ligarreto, G., M. Patiño, and S. Magnitskiy. 2011. Phenotypic plasticity of Vaccinium meridionale (Ericaceae) in wild populations of mountain forests in Colombia. Rev. Biol. Trop. 59(2), 569-583.

López, É.P., L.M. Martínez, C.A. Martínez-Cañas, and A. Vargas-Prieto. 2018. Desarrollo rural y envejecimiento: caso de estudio municipio de Chinavita, Boyaca, Colombia. Rev. Investig. Desarro. Innov. 8(2), 193-206. Doi: 10.19053/20278306.v8.n2.2018.7959

Luteyn, J.L. 1989. Speciation and diversity of Ericaceae in Neotropical montane vegetation. Tropical Forests. pp. 297-310. In: Holm-Nielsen, L.B., I.C. Nielsen, and H. Balslev (eds.). Tropical forests. Botanical dynamics, speciation and diversity. Academic Press, London. Doi: 10.1016/b978-0-12-353550-4.50031-9

Magnitskiy, S. and G. Ligarreto. 2009. Plantas de agraz o mortiño (Vaccinium meridionale Swartz): potencial de propagación sexual. pp. 75-91. In: Ligarreto, G. (ed.). Perspectivas del cultivo de agraz o mortiño (Vaccinium meridionale Swartz) en la zona altoandina de Colombia. Universidad Nacional de Colombia, Bogota.

MADR, Ministerio de Agricultura y Desarrollo Rural de Colombia. 2019. Plan integral de desarrollo agropecuario y rural con enfoque territorial. Departamento de Boyacá. In: https://www.adr.gov.co/servicios/ 
pidaret/BOYACA\%20TOMO\%20II.pdf; consulted: September, 2019.

Mendoza, G. 1995. Compendio de mercadeo de productos agropecuarios. $2^{\text {nd }}$ ed. Servicio Editorial IICA, San José.

Muchnik, J. 2006. Sistemas agroalimentarios localizados: evolución del concepto y diversidad de situaciones. pp 1-20. In: III Congreso Internacional de La Red SYAL "Alimentación y Territorios". ALTER, Baeza, Spain.

Muchnik, J. and D. Sautier. 1998. Systèmes agro-alimentaires localisés et construction de territoires. Proposition d'action thématique programmée. CIRAD, Paris.

Muñoz, J.D., L.J. Martínez, and G. Ligarreto. 2009. Caracterización de los ambientes agroecológicos del agraz o mortiño (Vaccinium meridionale Swartz), en la zona altoandina de Colombia. pp. 29-56. In: Ligarreto, G. (ed.). Perspectivas del cultivo de agraz o mortiño (Vaccinium meridionale Swartz) en la zona altoandina de Colombia. Universidad Nacional de Colombia, Bogota.

Neumeier, S. 2017. Social innovation in rural development: identifying the key factors of success. Geograph. J. 183(1), 34-46. Doi: https://doi.org/10.1111/ geoj.12180

Quevedo-Rubiano, S. 2020. Caracterización bajo el enfoque SIAL y análisis de la competitividad sistémica: el caso del agraz de las provincias de Occidente y Ricaurte (Boyacá-Colombia). MSc thesis. Facultad de Ciencias Agrarias, Universidad Nacional de Colombia, Bogota.

Quintero-Quiroz, J., Y. Galvis-Pérez, S. Galeano-Vasquez, C. Marin-Echeverri, C. Franco-Escobar, G. Ciro-Gomez, and J. Barona-Acevedo. 2019. Physico-chemical characterization and antioxidant capacity of the colombian berry (Vaccinium meridionale Swartz) with a high-polyphenol content: potential effects in people with metabolic syndrome. Food Sci.Technol. 39(3), 573-582. Doi: 10.1590/fst.32817

Ray, C. 1998. Culture, intellectual property and territorial rural development. Sociol. Ruralis 38(1), 3-20. Doi: 10.1111/1467-9523.00060
Red SYAL México. 2019. Diez años de contribución a los estudios de los sistemas agroalimentarios localizados. IICA, Mexico, DF. Doi: 10.1017/ CBO9781107415324.004

Rodríguez-Borray, G. and C. Rangel-Moreno. 2005. Estudio del sistema agroalimentario localizado, SYAL, de la concentración de fábricas de bocadillo de guayaba en las provincias de Vélez y Ricaurte en Colombia. Corpoica, Bogota.

Rubiano, E. 2017. Estimación de las pérdidas de papa en los canales de distribución y estrategias para el mejoramiento de la SAN. MSc thesis. Facultad de Medicina, Universidad Nacional de Colombia, Bogota.

Santacruz, A.M., G. Rodríguez-Borray, and Y. Aranda-Camacho. 2019. Competitividad sistémica del Sistema Agroalimentario Localizado (SIAL) de la piña de El Peñón (departamento de Bolivar, Colombia). Agroalimentaria 25(49), 89-106.

Tolentino, J., Larrao, R., Renard, M., \& Del Valle, M. 2018. Sistemas Agroalimentarios Localizados y prácticas agrícolas tradicionales. Hacia una propuesta de política pública para el desarrollo rural. Editorial Yod, Ciudad de Mexico.

Torre, A., and A. Rallet. 2005. Proximity and localization. Regional Studies 39(1), 47-59. Doi: 10.1080/0034340052000320842

Torres, G. 2013. Sistemas agroalimentarios localizados. Innovación y debates desde América Latina. INTERthesis 10(2), 68-94. Doi: 10.5007/1807-1384.2013v10n2p68

Torres, W., Montoya, I., and G. Ligarreto. 2009. Aspectos sociales y económicos de la producción de agraz o mortiño (Vaccinium meridionale Swartz). pp. 113-134. In: Ligarreto, G. (ed.). Perspectivas del cultivo de agraz o mortiño (Vaccinium meridionale Swartz) en la zona altoandina de Colombia. Universidad Nacional de Colombia, Bogota.

Vega-Castro, O. and F. López-Barón. 2012. Alimentos típicos de Boyacá, Colombia. Perspect. Nut. Hum. 14(2), 21-30. 